\title{
Complete genome sequence of Meiothermus silvanus type strain (VI-R2 $\left.{ }^{\top}\right)$
}

\author{
Johannes Sikorski ${ }^{1}$, Brian J Tindall ${ }^{1}$, Stephen Lowry ${ }^{2}$, Susan Lucas ${ }^{2}$, Matt Nolan' ${ }^{2}$, Alex \\ Copeland ${ }^{2}$, Tijana Glavina Del Rio ${ }^{2}$, Hope Tice², Jan-Fang Cheng' ${ }^{2}$ Cliff Han $^{2,3}$, Sam Pitluck², \\ Konstantinos Liolios ${ }^{2}$, Natalia Ivanova ${ }^{2}$, Konstantinos Mavromatis ${ }^{2}$, Natalia Mikhailova ${ }^{2}$, \\ Amrita Pati ${ }^{2}$, Lynne Goodwin ${ }^{2,3}$, Amy Chen ${ }^{4}$, Krishna Palaniappan ${ }^{4}$, Miriam Land ${ }^{2,5}$, Loren \\ Hauser $^{2,5}$, Yun-Juan Chang ${ }^{2,5}$, Cynthia D. Jeffries ${ }^{2,5}$, Manfred Rohde ${ }^{6}$, Markus Göker ${ }^{1}$, Tanja \\ Woyke $^{2}$, James Bristow ${ }^{2}$, Jonathan A. Eisen ${ }^{2,7}$, Victor Markowitz ${ }^{4}$, Philip Hugenholtz ${ }^{2}$, Nikos \\ C. Kyrpides ${ }^{2}$, Hans-Peter Klenk ${ }^{1}$, and Alla Lapidus ${ }^{2 *}$ \\ ${ }^{1}$ DSMZ - German Collection of Microorganisms and Cell Cultures GmbH, Braunschweig, \\ Germany \\ ${ }^{2}$ DOE Joint Genome Institute, Walnut Creek, California, USA \\ ${ }^{3}$ Los Alamos National Laboratory, Bioscience Division, Los Alamos, New Mexico, USA \\ ${ }^{4}$ Biological Data Management and Technology Center, Lawrence Berkeley National \\ Laboratory, Berkeley, California, USA \\ ${ }^{5}$ Oak Ridge National Laboratory, Oak Ridge, Tennessee, USA \\ ${ }^{6} \mathrm{HZI}$ - Helmholtz Centre for Infection Research, Braunschweig, Germany \\ ${ }^{7}$ University of California Davis Genome Center, Davis, California, USA \\ *Corresponding author: Alla Lapidus
}

Keywords: thermophilic, aerobic, biofouler, colored biofilm in paper industry, Gramnegative, Thermales, Deinococci, GEBA

Meiothermus silvanus (Tenreiro et al. 1995) Nobre et al. 1996 belongs to a thermophilic genus whose members share relatively low degrees of 16S rRNA gene sequence similarity. Meiothermus constitutes an evolutionary lineage separate from members of the genus Thermus, from which they can generally be distinguished by their slightly lower temperature optima. M. silvanus is of special interest as it causes colored biofilms in the paper making industry and may thus be of economic importance as a biofouler. This is the second completed genome sequence of a member of the genus Meiothermus and only the third genome sequence to be published from a member of the family Thermaceae. The 3,721,669 bp long genome with its 3,667 protein-coding and 55 RNA genes is a part of the Genomic Encyclopedia of Bacteria and Archaea project.

\section{Introduction}

Strain VI-R2T $(\mathrm{T}$ (= DSM $9946=$ ATCC $700542=$ BCRC 17112) was first described as 'Thermus silvanus' by Tenreiro et al. in 1995 [1]. One year later it was formally named and transferred from the genus Thermus into the then novel genus Meiothermus by Nobre et al. [2]. Currently, there are nine species within the genus Meiothermus [3,4]. The genus name derives from the Greek words 'meion' and 'thermos' meaning 'lesser' and 'hot' to indicate an organism in a less hot place $[2,3]$. The species name was given in honor of Manuel T. Silva, a Portuguese microbiologist and immunologist [1]. Strain VI-R2T was isolated from the hot spring (vent temperature, $56^{\circ} \mathrm{C} ; \mathrm{pH} 8.9$ ) located at the end of a $450 \mathrm{~m}$ tunnel and from thermal water (temperature $33^{\circ} \mathrm{C}$; $\mathrm{pH} 8.8$ ) piped to a spa at Vizela in northern Portugal [1].

Members of the genus Meiothermus have been isolated from natural hot springs and artificial thermal environments [2,5] in Russia [6], Central France [7], Northern and Central Portugal [1,8], NorthEastern China [9], Northern Taiwan [10], Iceland [11] and the Azores [4]. Interestingly, the genus Meiothermus is heterogeneous with respect to pigmentation. The yellow pigmented species also form 
a distinct group on the basis of the 16S rRNA gene sequence similarity, whereas the red/orange pigmented strains form two groups, one comprising $M$. silvanus and the other the remaining species $[8,9]$. Like all members of the class Deinococci, the lipid composition of the cell membrane of members of the genus Meiothermus contains unusual and characteristic structures.

M. silvanus is well known to form colored biofilms in the paper industry, which makes this species an economic threat $[12,13]$. M. silvanus uses threadlike organelles for adhesion and biofilm formation to grow on stainless steel [14]. However, coating of stainless steel with diamond-like carbon or certain fluoropolymers reduced or almost eliminated adhesion and biofilm growth of $M$. silvanus [14]. Other strategies to combat $M$. silvanus in the paper industry include electrochemical inactivation (oxidation) using different levels of chloride concentration [15]. Here, the inactivation was mainly due to the electrochemically generated chlorine/hypochlorite [15]. A patent based on different natural plant extracts inhibiting biofilm formation of thermophilic species in paper or board machines, amongst them M. silvanus, has been recently issued [16].

The 16S rRNA genes of the seven other type strains in the genus Meiothermus share between 88.5\% (Meiothermus chliarophilus [1]) and 89.8\% (Meiothermus cerbereus [11]) sequence identity with strain VI-R2 ${ }^{\mathrm{T}}$, whereas the other type strains from the family Thermaceae share 85.8 to $87.8 \%$ sequence identity [17]. In addition to being found on paper and board machines [12] uncultured clone 16S rRNA gene sequences very similar to $M$. silvanus VI-R2 ${ }^{\mathrm{T}}$ (X84211) have also been detected in the gut of an invasive wood-boring beetle (98\% identity, EU148672) [18] and in seawater adjacent to a
Pacillopora meandrina coral colony at Palmyra Atoll (99\% identity, EU249942). Environmental samples and metagenomic surveys do not surpass $84 \%$ sequence similarity to the $16 \mathrm{~S}$ rRNA gene sequence of strain VI-R2 ${ }^{\mathrm{T}}$ (status May 2010). Here we present a summary classification and a set of features for M. silvanus VI-R2T, together with the description of the complete genomic sequencing and annotation.

\section{Classification and features}

A physiological description based on five strains of the species is given by Tenreiro et al. [1]. The cells are described as Gram-negative nonmotile rods with variable lengths and 0.5 to $0.8 \mu \mathrm{m}$ in width (Table 1 and Figure 1). On Thermus medium colonies are orange-red pigmented and 0.5 to $1.2 \mu \mathrm{m}$ in diameter after $72 \mathrm{~h}$ of growth [1]. The optimum $\mathrm{pH}$ is between 8.0 and 8.5; growth does not occur at $\mathrm{pH}$ 5.0 or 10.0. Yeast extract is required for growth [1]. All strains are oxidase positive and catalase negative. Nitrate is reduced to nitrite. Strain VI-R2 ${ }^{\mathrm{T}}$ is negative for the enzyme $\alpha$-galactosidase but positive for $\beta$-galactosidase. Casein, elastin, gelatin, hide powder azure, and starch are degraded. The hydrolysis of fibrin is weak or negative. Strain VI-R2 ${ }^{\mathrm{T}}$ utilizes D-glucose, D-fructose, D-mannose, D-galactose, D-xylose, maltose, lactose, D-melibiose, glycerol, Dmannitol, D-sorbitol, ribitol, pyruvate, L-glutamate, L-asparagine, L-serine, L-glutamine, and L-proline [1]. Strain VI-R2T does not utilize L-arabinose, Lrhamnose, sucrose, D-cellobiose, D-trehalose, Draffinose, meso-erythritol, galactitol, myo-inositol, acetate, succinate, citrate, salicin, or acetamide [1]. Further metabolic traits are listed elsewhere [7]. Also, strain VI-R2 ${ }^{\mathrm{T}}$ produces polysaccharide inclusions [1].

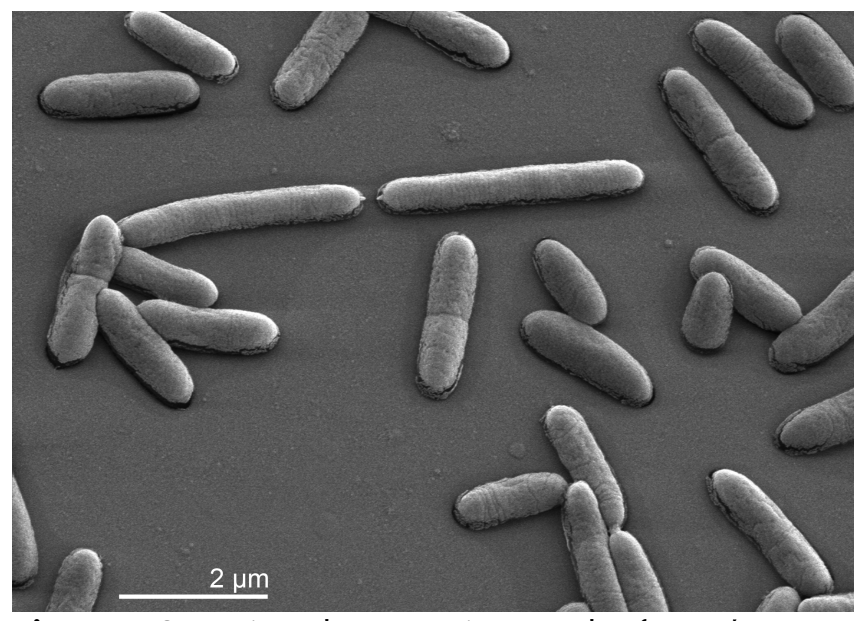

Figure 1. Scanning electron micrograph of M. silvanus $\mathrm{VI}-\mathrm{R} 2^{\top}$. 
Figure 2 shows the phylogenetic neighborhood of M. silvanus VI-R2T in a $16 \mathrm{~S}$ rRNA-based tree. The sequences of the two 16S rRNA gene copies in the genome of $M$. silvanus VI-R2 ${ }^{\mathrm{T}}$ do not differ from each other, but differ by six nucleotides from the previously published 16S rRNA sequence from DSM 9946 (X84211).

\section{Chemotaxonomy}

Thin-layer chromatography of the polar lipids from $M$. silvanus revealed a single phospholipid
(PL-2) and two prominent glycolipids GL-la and GL-lb [37]. Although the structure of the major phospholipid has not been investigated from $M$. silvanus it has the same $\mathrm{Rf}$ value as the 2 '-0-(1, 2diacyl-sn-glycero-3-phospho) -3'-O- $(\alpha-\mathrm{N}$-acetylglucosaminyl)-N-glyceroyl alkylamine from $M$. ruber [38]. The glycolipids are derivatives of a Glcp$>$ Galp-> GalNAcyl-> Glcp-> diacyl glycerol [37].

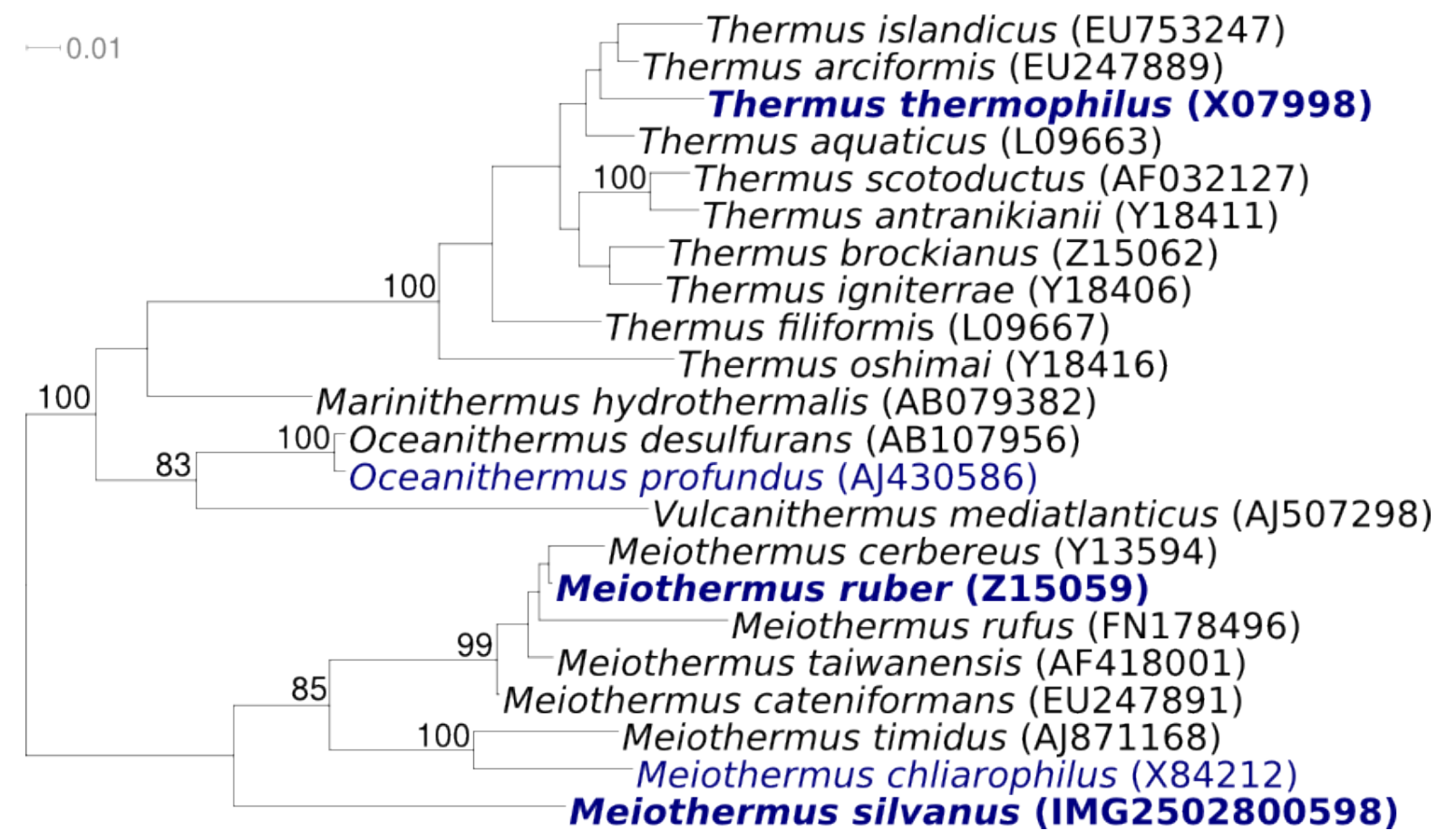

Figure 2. Phylogenetic tree highlighting the position of $M$. silvanus $\mathrm{VI}-\mathrm{R} 2^{\top}$ relative to the type strains of the other species within the genus and to the other type strains within the family Thermaceae. The tree was inferred from 1,442 aligned characters [30,31] of the 16S rRNA gene sequence under the maximum likelihood criterion [32] and rooted in accordance with the current taxonomy [33]. The branches are scaled in terms of the expected number of substitutions per site. Numbers above branches are support values from 900 bootstrap replicates [34] if larger than 60\%. Lineages with type strain genome sequencing projects registered in GOLD [35] are shown in blue, published genomes in bold, i.e. Thermus thermophilus (AP008226) and the type species of the genus, M. ruber [36].

Based on mass spectral data it appears that there may be three distinct derivatives, differing in the fatty acid amide linked to the galactosamine [37]. These may be divided into one compound containing exclusively 2-hydroxylated fatty acids (mainly 2-OH iso-17:0) and a mixture of two compounds that cannot be fully resolved by thin layer chromatography, carrying either 3-hydroxylated fatty acids or unsubstituted fatty acids. The basic glycolipid structure dihexosyl - N-acyl-hexosaminyl - hexosyl - diacylglycerol is a feature common to all members of the genera Thermus and Meiothermus examined to date. There is currently no evidence that members of the family Thermaceae (as currently defined) produce significant amounts of polar lipids containing only two aliphatic side chains. The consequences of having polar lipids containing three aliphatic side chains on membrane structure has yet to be examined. Such peculiarities also indicate the value of membrane 
composition in helping to unravel evolution at a cellular level [36]. The major fatty acids of the total polar lipids are anteiso- $\mathrm{C}_{15: 0}(22.4 \%)$, iso- $\mathrm{C}_{15: 0}$ $(16.8 \%)$ and iso- $\mathrm{C}_{18: 0}(12.2 \%)$, followed by iso$\mathrm{C}_{17: 0}-2 \mathrm{OH}(10.5 \%)$ and iso- $\mathrm{C}_{17: 0}$ and anteiso- $\mathrm{C}_{17: 0}$ (each $8.5 \%$ ) [37]. The glycolipid GL-la is characterized by a large amount of the fatty acid iso- $\mathrm{C}_{17: 0^{-}}$
$20 \mathrm{H}(19.2 \%)$, which is nearly completely absent from GL-lb and the phospholipid PL-2 [37]. Menaquinone 8 was the only respiratory lipoquinone detected in all strains [1]. The structure of the red pigment has not been characterized in contrast to that of M. ruber [39].

Table 1. Classification and general features of M. silvanus VI-R2 according to the MIGS recommendations [19]

\begin{tabular}{|c|c|c|c|}
\hline MIGS ID & Property & Term & Evidence code \\
\hline & \multirow{8}{*}{ Current classification } & Domain Bacteria & TAS [20] \\
\hline & & Phylum 'Deinococcus -Thermus & TAS $[21,22]$ \\
\hline & & Class Deinococci & TAS [23-25] \\
\hline & & Order Thermales & TAS $[26,27]$ \\
\hline & & Family Thermaceae & TAS $[24,27]$ \\
\hline & & Genus Meiothermus & TAS $[2,7]$ \\
\hline & & Species Meiothermus silvanus & TAS $[1,6]$ \\
\hline & & Type strain VI-R2 & TAS [6] \\
\hline & Gram stain & negative & TAS [1] \\
\hline & Cell shape & rod & TAS [1] \\
\hline & Motility & nonmotile & TAS [1] \\
\hline & Sporulation & no & TAS [1] \\
\hline & Temperature range & $40^{\circ} \mathrm{C}-65^{\circ} \mathrm{C}$ & TAS [1] \\
\hline & Optimum temperature & $55^{\circ} \mathrm{C}$ & TAS [1] \\
\hline & Salinity & does not grow with $1 \%$ or more $\mathrm{NaCl}$ & TAS [1] \\
\hline \multirow[t]{3}{*}{ MIGS-22 } & Oxygen requirement & aerobic & TAS [1] \\
\hline & Carbon source & a diverse set of sugars & TAS [1] \\
\hline & Energy source & carbohydrates & TAS [1] \\
\hline MIGS-6 & Habitat & hot springs & TAS [1] \\
\hline MIGS-15 & Biotic relationship & free-living & TAS [1] \\
\hline \multirow[t]{3}{*}{ MIGS-14 } & Pathogenicity & not reported & \\
\hline & Biosafety level & 1 & TAS [28] \\
\hline & Isolation & hot spring & TAS [1] \\
\hline MIGS-4 & Geographic location & Vizela, Portugal & TAS [1] \\
\hline MIGS-5 & Sample collection time & 1995 or before & TAS [1] \\
\hline $\begin{array}{l}\text { MIGS-4.1 } \\
\text { MIGS-4.2 }\end{array}$ & $\begin{array}{l}\text { Latitude } \\
\text { Longitude }\end{array}$ & $\begin{array}{r}41.38 \\
8.32\end{array}$ & NAS \\
\hline MIGS-4.3 & Depth & unknown & \\
\hline MIGS-4.4 & Altitude & $157 \mathrm{~m}$ & NAS \\
\hline
\end{tabular}

Evidence codes - IDA: Inferred from Direct Assay (first time in publication); TAS: Traceable Author Statement (i.e., a direct report exists in the literature); NAS: Non-traceable Author Statement (i.e., not directly observed for the living, isolated sample, but based on a generally accepted property for the species, or anecdotal evidence). These evidence codes are from of the Gene Ontology project [29]. If the evidence code is IDA, then the property was directly observed by one of the authors or an expert mentioned in the acknowledgements. 


\section{Genome sequencing and annotation Genome project history}

This organism was selected for sequencing on the basis of its phylogenetic position [40], and is part of the Genomic Encyclopedia of Bacteria and Archaea project [41]. The genome project is deposited in the Genome OnLine Database [35] and the complete genome sequence is deposited in GenBank. Sequencing, finishing and annotation were performed by the DOE Joint Genome Institute (JGI). A summary of the project information is shown in Table 2.

Table 2. Genome sequencing project information

\begin{tabular}{|c|c|c|}
\hline MIGS ID & Property & Term \\
\hline MIGS-31 & Finishing quality & Finished \\
\hline MIGS-28 & Libraries used & $\begin{array}{l}\text { Three genomic libraries: Sanger } 8 \mathrm{~kb} \\
\text { pMCL200 and fosmid libraries, one } 454 \\
\text { pyrosequence standard library }\end{array}$ \\
\hline MIGS-29 & Sequencing platforms & ABI3730, 454 Titanium, Illumina GAii \\
\hline MIGS-31.2 & Sequencing coverage & $8.3 \times$ Sanger; $16.6 \times$ pyrosequence \\
\hline MIGS-30 & Assemblers & Newbler version 1.1.02.15, Arachne \\
\hline \multirow[t]{6}{*}{ MIGS-32 } & Gene calling method & Prodigal 1.4, GenePRIMP \\
\hline & INSDC ID & $\begin{array}{l}\text { CP002042 chromosome } \\
\text { CP002043 plasmid pMESIL01 } \\
\text { CP002044 plasmid pMESIL02 }\end{array}$ \\
\hline & Genbank Date of Release & June 4, 2010 \\
\hline & GOLD ID & Gc01327 \\
\hline & NCBI project ID & 29551 \\
\hline & Database: IMG-GEBA & 2502790002 \\
\hline \multirow[t]{2}{*}{ MIGS-13 } & Source material identifier & DSM 9946 \\
\hline & Project relevance & Tree of Life, GEBA \\
\hline
\end{tabular}

\section{Growth conditions and DNA isolation}

M. silvanus VI-R2', DSM 9946, was grown in DSMZ medium 86 (Castenholz Medium) [42] at $50^{\circ} \mathrm{C}$. DNA was isolated from $0.5-1 \mathrm{~g}$ of cell paste using Qiagen Genomic 500 DNA Kit (Qiagen, Hilden, Germany) following the standard protocol as recommended by the manufacturer, with modification st/LALMP as described in Wu et al. [41].

\section{Genome sequencing and assembly}

The genome was sequenced using a combination of Sanger and 454 sequencing platforms. All general aspects of library construction and sequencing can be found at the IGI website. Pyrosequencing reads were assembled using the Newbler assembler version 1.1.02.15 (Roche). Large Newbler contigs were broken into 3,908 overlapping fragments of $1,000 \mathrm{bp}$ and entered into assembly as pseudo-reads. The sequences were assigned quality scores based on Newbler consensus qscores with modifications to account for overlap redundancy and adjust inflated q-scores. A hybrid 454/Sanger assembly was made using the Arachne assembler. Possible misassemblies were corrected and gaps between contigs were closed editing in Consed, custom primer walks from sub-clones or PCR products. A total of 323 Sanger finishing reads were produced to close gaps, to resolve repetitive regions, and to raise the quality of the finished sequence. 9,068,515 Illumina reads were used to improve the final consensus quality using an in-house developed tool (the Polisher) [43]. The error rate of the completed genome sequence is less than 1 in 100,000. Together, the combination of the Sanger and 454 se- 
quencing platforms provided $26.9 \times$ coverage of the genome. The final assembly contains 42,181 Sanger reads and 335,557 pyrosequencing reads.

\section{Genome annotation}

Genes were identified using Prodigal [44] as part of the Oak Ridge National Laboratory genome annotation pipeline, followed by a round of manual curation using the IGI GenePRIMP pipeline [45]. The predicted CDSs were translated and used to search the National Center for Biotechnology Information (NCBI) nonredundant database, UniProt, TIGRFam, Pfam, PRIAM, KEGG, COG, and InterPro databases. Additional gene prediction analysis and functional annotation was performed within the Integrated Microbial
Genomes - Expert Review (IMG-ER) platform [46].

\section{Genome properties}

The genome consists of a 3,249,394 bp long chromosome, and two plasmids of $347,854 \mathrm{bp}$ and $124,421 \mathrm{bp}$ lengths, respectively, with a total $\mathrm{G}+\mathrm{C}$ content of $62.7 \%$ (Figure 3 and Table 3). Of the 3,722 genes predicted, 3,667 were proteincoding genes, and 55 RNAs; 158 pseudogenes were also identified. The majority of the proteincoding genes $(64.5 \%)$ were assigned a putative function while the remaining ones were annotated as hypothetical proteins. The distribution of genes into COGs functional categories is presented in Table 4.
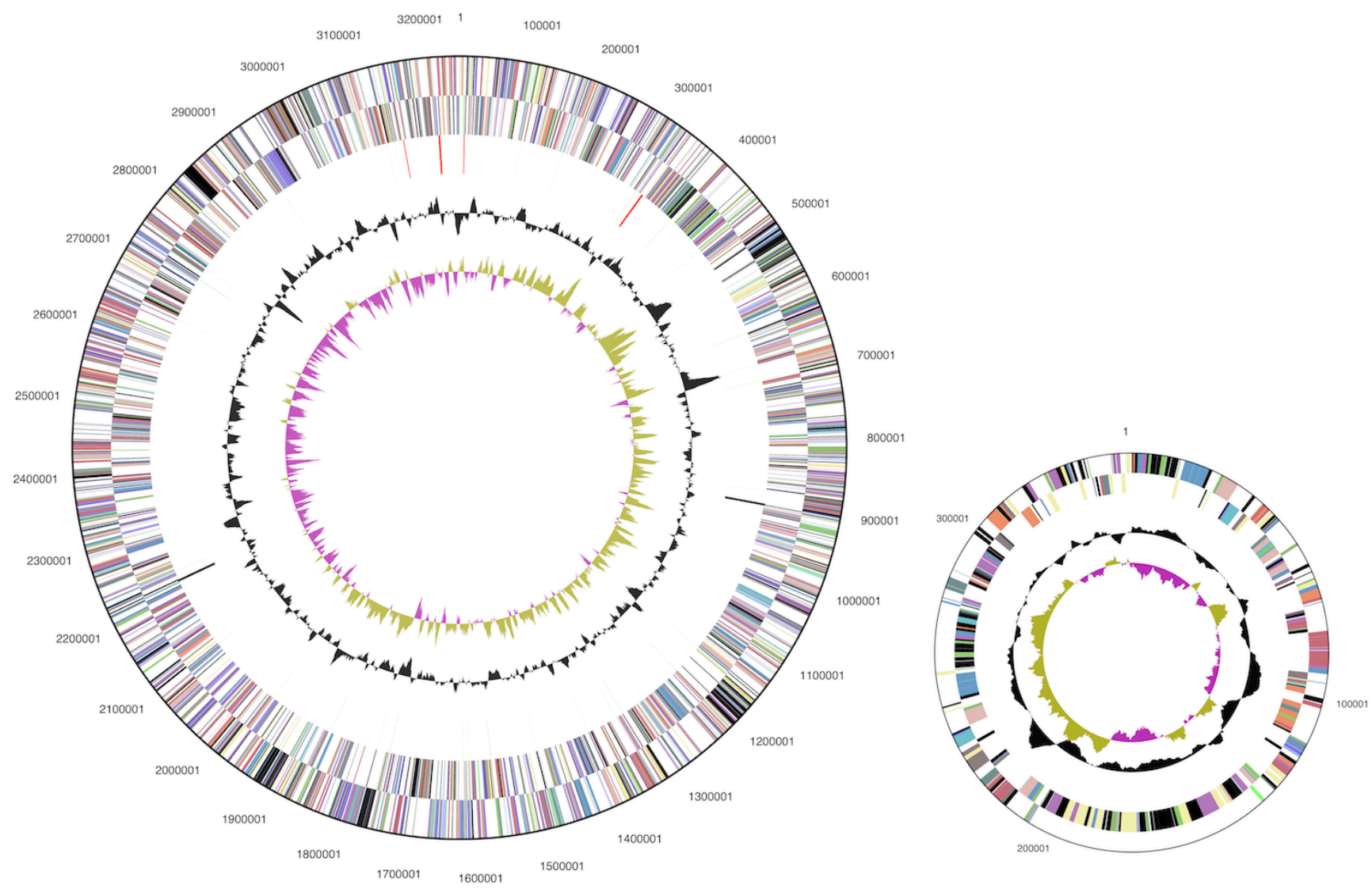

Figure 3. Graphical circular map of the genome and the larger of the two plasmids (not drawn to scale). From outside to the center: Genes on forward strand (color by COG categories), Genes on reverse strand (color by COG categories), RNA genes (tRNAs green, rRNAs red, other RNAs black), GC content, GC skew. 
Table 3. Genome Statistics

\begin{tabular}{lrr}
\hline Attribute & Value & \% of Total \\
\hline Genome size (bp) & $3,721,669$ & $100.00 \%$ \\
DNA Coding region (bp) & $3,283,226$ & $88.22 \%$ \\
DNA G+C content (bp) & $2,334,056$ & $62.72 \%$ \\
Number of replicons & 3 & \\
Extrachromosomal elements & 2 & \\
Total genes & 3,722 & $100.00 \%$ \\
RNA genes & 55 & $1.48 \%$ \\
rRNA operons & 2 & \\
Protein-coding genes & 3,667 & $98.52 \%$ \\
Pseudo genes & 158 & $4.25 \%$ \\
Genes with function prediction & 2,400 & $64.48 \%$ \\
Genes in paralog clusters & 740 & $19.89 \%$ \\
Genes assigned to COGs & 2,530 & $67.97 \%$ \\
Genes assigned Pfam domains & 2,797 & $75.15 \%$ \\
Genes with signal peptides & 1,249 & $33.56 \%$ \\
Genes with transmembrane helices & 796 & $21.39 \%$ \\
CRISPR repeats & 16 & \\
\hline
\end{tabular}

Table 4. Number of genes associated with the general COG functional categories

\begin{tabular}{|c|c|c|c|}
\hline Code & value & \%age & Description \\
\hline J & 151 & 5.4 & Translation, ribosomal structure and biogenesis \\
\hline A & 0 & 0.0 & RNA processing and modification \\
\hline K & 166 & 6.0 & Transcription \\
\hline $\mathrm{L}$ & 195 & 7.0 & Replication, recombination and repair \\
\hline B & 2 & 0.1 & Chromatin structure and dynamics \\
\hline $\mathrm{D}$ & 33 & 1.2 & Cell cycle control, cell division, chromosome partitioning \\
\hline Y & 0 & 0.0 & Nuclear structure \\
\hline V & 43 & 1.6 & Defense mechanisms \\
\hline $\mathrm{T}$ & 120 & 4.3 & Signal transduction mechanisms \\
\hline M & 128 & 4.6 & Cell wall/membrane/envelope biogenesis \\
\hline N & 26 & 0.9 & Cell motility \\
\hline Z & 0 & 0.0 & Cytoskeleton \\
\hline W & 0 & 0.0 & Extracellular structures \\
\hline U & 53 & 1.9 & Intracellular trafficking, secretion, and vesicular transport \\
\hline $\mathrm{O}$ & 107 & 5.5 & Posttranslational modification, protein turnover, chaperones \\
\hline C & 168 & 6.1 & Energy production and conversion \\
\hline G & 218 & 7.9 & Carbohydrate transport and metabolism \\
\hline $\mathrm{E}$ & 292 & 10.5 & Amino acid transport and metabolism \\
\hline $\mathrm{F}$ & 85 & 3.1 & Nucleotide transport and metabolism \\
\hline $\mathrm{H}$ & 110 & 4.0 & Coenzyme transport and metabolism \\
\hline I & 88 & 3.2 & Lipid transport and metabolism \\
\hline$P$ & 152 & 5.5 & Inorganic ion transport and metabolism \\
\hline Q & 52 & 1.9 & Secondary metabolites biosynthesis, transport and catabolism \\
\hline $\mathrm{R}$ & 362 & 13.0 & General function prediction only \\
\hline S & 227 & 8.2 & Function unknown \\
\hline- & 1,192 & 32.0 & Not in COGs \\
\hline
\end{tabular}




\section{Acknowledgements}

We would like to gratefully acknowledge the help of Helga Pomrenke for growing M. silvanus cultures and Susanne Schneider for DNA extraction and quality analysis (both at DSMZ). This work was performed under the auspices of the US Department of Energy Office of Science, Biological and Environmental Research Program, and by the University of California, Lawrence Berkeley National Laboratory under contract No. DE-

\section{References}

1. Tenreiro S, Nobre MF, da Costa MS. Thermus silvanus sp. nov. and Thermus chliarophilus sp. nov., two new species related to Thermus ruber but with lower growth temperatures. Int I Syst Bacteriol 1995; 45:633-639. PubMed doi:10.1099/00207713-45-4-633

2. Nobre MF, Trüper HG, Da Costa MS. Transfer of Thermus ruber (Loginova et al. 1984), Thermus silvanus (Tenreiro et al. 1995), and Thermus chliarophilus (Tenreiro et al. 1995) to Meiothermus gen. nov. as Meiothermus ruber comb. nov., Meiothermus silvanus comb. nov., and Meiothermus chliarophilus comb. nov., respectively, and emendation of the genus Thermus. Int / Syst Bacteriol 1996; 46:604-606. doi:10.1099/0020771346-2-604

3. Euzéby JP. List of bacterial names with standing in nomenclature: A folder available on the Internet. Int J Syst Bacteriol 1997; 47:590-592. PubMed doi:10.1099/00207713-47-2-590

4. Albuquerque L, Rainey FA, Nobre MF, da Costa MS. Meiothermus granaticius sp. nov., a new slightly thermophilic red-pigmented species from the Azores. System Appl Microbiol 2010; Epub ahead of print May 6, 2010

5. Masurat P, Fru EC, Pedersen K. Identification of Meiothermus as the dominant genus in a storage system for spent nuclear fuel. J App/ Microbiol 2005; 98:727-740. PubMed doi:10.1111/j.13652672.2004.02519.x

6. Loginova LG, Egorova LA, Golovacheva RS, Seregina LM. Thermus ruber sp. nov., nom. rev. Int J Syst Bacteriol 1984; 34:498-499. doi:10.1099/00207713-34-4-498

7. Albuquerque L, Ferreira C, Tomaz D, Tiago I, Veríssimo A, da Costa MS, Nobre MF. Meiothermus rufus sp. nov., a new slightly thermophilic red-pigmented species and emended description of the genus Meiothermus. Syst Appl Microbiol 2009; 32:306-313. PubMed doi:10.1016/j.syapm.2009.05.002
AC02-05CH11231, Lawrence Livermore National Laboratory under Contract No. DE-AC52-07NA27344, and Los Alamos National Laboratory under contract No. DEAC02-06NA25396, UT-Battelle and Oak Ridge National Laboratory under contract DE-AC05-000R22725, as well as German Research Foundation (DFG) INST 599/1-2 and SI 1352/1-2.

8. Pires AL, Albuquerque L, Tiago I, Nobre MF, Empadinhas N, Veríssimo A, da Costa MS. Meiothermus timidus sp. nov., a new slightly thermophilic yellow-pigmented species. FEMS Microbiol Lett 2005; 245:39-45. PubMed doi:10.1016/j.femsle.2005.02.011

9. Zhang XQ, Zhang WJ, Wei BP, Xu XW, Zhu XF, Wu M. Meiothermus cateniformans sp. nov., a slightly thermophilic species from north-eastern China. Int J Syst Evol Microbiol 2010; 60:840844. PubMed doi:10.1099/ijs.0.007914-0

10. Chen MY, Lin GH, Lin YT, Tsay SS. Meiothermus taiwanensis sp. nov., a novel filamentous, thermophilic species isolated in Taiwan. Int I Syst Evol Microbiol 2002; 52:1647-1654. PubMed doi:10.1099/ijs.0.02189-0

11. Chung AP, Rainey F, Nobre MF, Burghardt J, Costa MSD. Meiothermus cerbereus sp. nov., a new slightly thermophilic species with high levels of 3hydroxy fatty acids. Int I Syst Bacteriol 1997; 47:1225-1230. PubMed doi:10.1099/00207713$\underline{47-4-1225}$

12. Ekman J, Kosonen M, Jokela S, Kolari M. Korhonen Pi, Salkinoja-Salonen M. Detection and quantitation of colored deposit-forming Meiothermus spp. in paper industry processes and end products. J Ind Microbiol Biotechnol 2007;

34:203-211. PubMed doi:10.1007/s10295-006$\underline{0187-z}$

13. Kolari M, Nuutinen J, Rainey FA, SalkinojaSalonen MS. Colored moderately thermophilic bacteria in paper-machine biofilms. J Ind Microbiol Biotechnol 2003; 30:225-238. PubMed

14. Raulio M, Järn M, Ahola J, Peltonen J, Rosenholm J, Tervakangas S, Kolehmainen J, Ruokolainen T, Narko P, Salkinoja-Salonen M. Microbe repelling coated stainless steel analysed by field emission scanning electron microscopy and physicochemical methods. I Ind Microbiol Biotechnol 2008; 35:751-760. PubMed doi:10.1007/s10295-008$\underline{0343-8}$ 
15. Särkkä H, Vepsäläinen $M$, Pulliainen $M$, Sillanpää $M$. Electrochemical inactivation of paper mill bacteria with mixed metal oxide electrode. I Hazard Mater 2008; 156:208-213. PubMed doi:10.1016/j.jhazmat.2007.12.011

16. Kolari M, Salkinoja-Salonen M, Laatikainen $\mathrm{H}$, Tammela P, Vuorela P, Vaatnen P, Hatunen TJ. 2006. Inhibiting biofilm formation by thermophilic microbes in paper and board machines. United States Patent.

17. Chun J, Lee JH, Jung $Y$, Kim M, Kim S, Kim BK, Lim YW. EzTaxon: a web-based tool for the identification of prokaryotes based on $16 \mathrm{~S}$ ribosomal RNA gene sequences. Int I Syst Evol Microbiol 2007; 57:2259-2261. PubMed doi:10.1099/ijs.0.64915-0

18. Vasanthakumar A, Handelsman J, Schloss PD, Bauer LS, Raffa KF. Gut microbiota of an invasive subcortical beetle, Agrilus planipennis Fairmaire, across various life stages. Environ Entomol 2008; 37:1344-1353. PubMed doi:10.1603/0046225X(2008)37[1344:GMOAIS]2.0.CO;2

19. Field D, Garrity G, Gray T, Morrison N, Selengut J, Sterk P, Tatusova T, Thomson N, Allen MJ, Angiuoli SV, et al. The minimum information about a genome sequence (MIGS) specification. Nat Biotechnol 2008; 26:541-547. PubMed doi:10.1038/nbt1360

20. Woese CR, Kandler O, Wheelis ML. Towards a natural system of organisms: proposal for the domains Archaea, Bacteria, and Eucarya. Proc Natl Acad Sci USA 1990; 87:4576-4579. PubMed doi:10.1073/pnas.87.12.4576

21. Garrity GM, Lilburn TG, Cole JR, Harrison SH, Euzéby J, Tindall BJ. Taxonomic outline of the Bacteria and Archaea, Release 7.7 March 6, 2007. Part 2 - The Bacteria: Phyla "Aquificae", "Thermotogae", "Thermodesulfobacteria", "Deinococcus-Thermus", "Chrysiogenetes", "Chloroflexi", "Thermomicrobia", "Nitrospira", "Deferribacteres", "Cyanobacteria", and "Chlorobi".

http://www.taxonomicoutline.org/

22. Weisburg WG, Giovannoni SJ, Woese CR. The Deinococcus-Thermus phylum and the effect of rRNA composition on phylogenetic tree construction. Syst Appl Microbiol 1989; 11:128-134. PubMed

23. Garrity GM, Holt JG. Class I. Deinococci class. nov. In: Garrity GM, Boone DR, Castenholz RW (eds), Bergey's Manual of Systematic Bacteriology, Second Edition, Volume 1, Springer, New York, 2001, p. 395.
24. List Editor. Validation List no. 85. Validation of publication of new names and new combinations previously effectively published outside the IJSEM. Int J Syst Evol Microbiol 2002; 52:685-690. PubMed doi:10.1099/ijs.0.02358-0

25. Garrity GM, Holt JG. Class I. Deinococci class. nov. In: Garrity GM, Boone DR, Castenholz RW (eds), Bergey's Manual of Systematic Bacteriology, Second Edition, Volume 1, Springer New York, 2001, p.395.

26. Rainey FA, da Costa MS. Order II. Thermales ord. nov. In: Garrity GM, Boone DR, Castenholz RW (eds), Bergey's Manual of Systematic Bacteriology, Second Edition, Volume 1, Springer, New York, 2001, p. 403.

27. daCosta MS, Rainey FA. Family I. Thermaceae fam. nov. In: Garrity GM, Boone DR, Castenholz RW (eds), Bergey's Manual of Systematics Bacteriology, Second Edition, Volume 1, Springer, New York, 2001, p. 403-404.

28. Classification of. Bacteria and Archaea in risk groups. http://www.baua.de TRBA 466.

29. Ashburner M, Ball CA, Blake JA, Botstein D, Butler H, Cherry JM, Davis AP, Dolinski K, Dwight SS, Eppig JT, et al. Gene Ontology: tool for the unification of biology. Nat Genet 2000; 25:25-29. PubMed doi:10.1038/75556

30. Castresana J. Selection of conserved blocks from multiple alignments for their use in phylogenetic analysis. Mol Biol Evol 2000; 17:540-552. PubMed

31. Lee C, Grasso C, Sharlow MF. Multiple sequence alignment using partial order graphs. Bioinformatics 2002; 18:452-464. PubMed doi:10.1093/bioinformatics/18.3.452

32. Stamatakis A, Hoover P, Rougemont J. A Rapid Bootstrap Algorithm for the RAxML Web Servers. Syst Biol 2008; 57:758-771. PubMed doi:10.1080/10635150802429642

33. Yarza P, Richter M, Peplies J, Euzeby J, Amann R, Schleifer KH, Ludwig W, Glöckner FO, RossellóMóra R. The All-Species Living Tree project: A $16 \mathrm{~S}$ rRNA-based phylogenetic tree of all sequenced type strains. Syst Appl Microbiol 2008; 31:241-250. PubMed doi:10.1016/j.syapm.2008.07.001

34. Pattengale ND, Alipour M, Bininda-Emonds ORP, Moret BME, Stamatakis A. How many bootstrap replicates are necessary? Lect Notes Comput Sci 2009; 5541:184-200. doi:10.1007/978-3-64202008-7_13 
35. Liolios K, Chen IM, Mavromatis K, Tavernarakis N, Hugenholtz P, Markovitzz VM, Kyrpides NC. The Genomes On Line Database (GOLD) in 2009: status of genomic and metagenomic projects and their associated metadata. Nucleic Acids Res 2010; 38:D346-D354. PubMed doi:10.1093/nar/gkp848

36. Tindall BJ, Sikorski J, Lucas S, Goltsman E, Copeland A, Glavina Del Rio T, Nolan M, Tica H, Cheng JF, Han C, et al. Complete genome sequence of Meiothermus ruber type strain $\left(21^{\mathrm{T}}\right)$. Stand Genomic Sci 2010; (this issue).

37. Ferreira AM, Wait R, Nobre MF, da Costa MS. Characterization of glycolipids from Meiothermus spp. Microbiology 1999; 145:1191-1199. $\underline{\text { PubMed doi:10.1099/13500872-145-5-1191 }}$

38. Yang YL, Yang FL, Jao SC, Chen MY, Tsay SS, Zou W, Wu SH. Structural elucidation of phosphoglycolipids from strains of the bacterial thermophiles Thermus and Meiothermus. J Lipid Res 2006;

47:1823-1832. PubMed doi:10.1194/jlr.M600034-JLR200

39. Burgess ML, Barrow KD, Gao C, Heard GM, Glenn D. Carotenoid glycoside esters from the thermophilic bacterium Meiothermus ruber. I Nat Prod 1999; 62:859-863. PubMed doi:10.1021/np980573d

40. Klenk HP, Göker M. En route to a genome-based classification of Archaea and Bacteria? Syst Appl Microbiol 2010; 33:175-182. PubMed doi:10.1016/j.syapm.2010.03.003
41. Wu D, Hugenholtz P, Mavromatis K, Pukall R, Dalin E, Ivanova NN, Kunin V, Goodwin L, Wu $\mathrm{M}$, Tindall BJ, et al. A phylogeny-driven genomic encyclopaedia of Bacteria and Archaea. Nature 2009; 462:1056-1060. PubMed doi:10.1038/nature08656

42. List of growth media used at DSMZ: http://www.dsmz.de/microorganisms/media_list.p hp.

43. Lapidus A, LaButti K, Foster B, Lowry S, Trong S, Goltsman E. POLISHER: an effective tool for using ultra short reads in microbial genome assembly and finishing. AGBT, Marco Island, FL, 2008.

44. Hyatt D, Chen GL, Locascio PF, Land ML, Larimer FW, Hauser LJ. Prodigal Prokaryotic Dynamic Programming Genefinding Algorithm. BMC Bioinformatics 2010; 11:119. PubMed doi:10.1186/1471-2105-11-119

45. Pati A, Ivanova N, Mikhailova N, Ovchinikova G, Hooper SD, Lykidis A, Kyrpides NC. GenePRIMP: A gene prediction improvement pipeline for microbial genomes. Nat Methods 2010; 7:455-457. PubMed doi:10.1038/nmeth.1457

46. Markowitz VM, Ivanova NN, Chen IMA, Chu K, Kyrpides NC. IMG ER: a system for microbial genome annotation expert review and curation. Bioinformatics 2009; 25:2271-2278. PubMed doi:10.1093/bioinformatics/btp393 